\title{
Vitamin D Deficiency and Associated Factors in Patients with Mental Disorders Treated in Routine Practice
}

\author{
Svetlana RisTic ${ }^{1}$, Sandra Zivanovic ${ }^{2}$, Dragan R. MILOVANOvic ${ }^{3, *}$, \\ Vladimir JANJIC ${ }^{4}$, Danijela DJoKovic ${ }^{4}$, Ana JoviceVIC ${ }^{1}$, \\ Marijana Stanojevic PIRKOvic ${ }^{5}$ and Sanja KocIC ${ }^{6}$ \\ ${ }^{1}$ Institute for Oncology and Radiology of Serbia, Belgrade, Serbia \\ ${ }^{2}$ Department of Medicine, Faculty of Hotel Management and Tourism, \\ University of Kragujevac, Vrnjacka Banja, Serbia \\ ${ }^{3}$ Department of Clinical Pharmacology, Clinical Centre "Kragujevac", Faculty of Medical Science, \\ University of Kragujevac, Svetozara Markovica 69, 34000 Kragujevac, Serbia \\ ${ }^{4}$ Clinic for Psychiatry, Clinical Centre "Kragujevac", Faculty of Medical Sciences, \\ University of Kragujevac, Kragujevac, Serbia \\ ${ }^{5}$ Department of Biochemistry, Faculty of Medical Sciences, University of Kragujevac, Kragujevac, Serbia \\ ${ }^{6}$ Public Health Institute Kragujevac, Faculty of Medical Sciences, \\ University of Kragujevac, Kragujevac, Serbia
}

(Received June 14, 2016)

\begin{abstract}
Summary This research aimed to investigate factors associated with vitamin D deficiency and to provide data about its prevalence in patients suffering from different psychiatric illnesses. The study had a cross-sectional design and it included 220 patients of both genders, aged from 19-81 y, with a wide range of mental disorders (F00-F89), and treated in routine ambulatory and hospital practice. The researchers collected data from three sources: medical records, a study questionnaire and biochemical analysis of patients' serum samples (concentration of vitamin D measured as $25(\mathrm{OH}) \mathrm{D}$, calcium, phosphorus, magnesium, sodium and potassium). Data were analyzed using descriptive statistics, methods for hypothesis testing and binary logistic regression, at the $p \leq 0.05$ level. A total of 140 patients $(64 \%)$ had a deficiency of vitamin D $(<12 \mathrm{ng} / \mathrm{mL})$, and $45(20 \%)$ had inadequate vitamin D serum levels (12-20 ng/mL), while 35 (16\%) had sufficient vitamin D serum concentrations $(>20 \mathrm{ng} / \mathrm{mL})$. Among variables related to demographics, life style habits, mental illness, comorbid disorders and drugs, two of them, female gender (odds ratio $(\mathrm{OR})=2.5,95 \%$ confidence interval $(\mathrm{CI})=1.3-4.9, p=0.006)$ and using clozapine $(\mathrm{OR}=15.6,95 \% \mathrm{CI} 1.7-$ $144.7, p=0.02)$, were significantly associated with vitamin D deficiency. Physical activity $(\mathrm{OR}=0.4,95 \% \mathrm{CI} 0.2-0.9, p=0.02)$, exercising $(\mathrm{OR}=0.2,95 \% \mathrm{CI}<0.1-0.7, p=0.02)$ and offal in the diet $(\mathrm{OR}=0.5,95 \% \mathrm{CI} 0.3-0.9, p=0.03)$ significantly aggregated in the patients who had a $25(\mathrm{OH}) \mathrm{D}$ serum concentration above the deficiency cut-off level. Patients with mental disorders are at high risk for vitamin D deficiency, particularly females and clozapine users as well as those having no adequate physical activity or dietary habits.
\end{abstract}

Key Words vitamin D, mental disorders, avitaminosis, risk factors, protective factors

The World Health Organization estimates that nearly half a billion people in the world suffer from a mental or behavioral disorder. In addition, mental disorders are responsible for one third of of the general population who live with a disability (1). On the other side, scientific findings about vitamin D are increasingly flooding contemporary medical literature, particularly the discussions over the most optimal serum levels and the best preventive strategies for those subjects being deficient in it. Data from population studies conducted in Europe, for example, indicate that at least four out of ten people had serum vitamin D concentrations clearly associated with many unhealthy outcomes, which raised questions relating to public health issues $(2,3)$. The knowledge

*To whom correspondence should be addressed.

E-mail: piki@medf.kg.ac.rs about the importance of vitamin D for human brain functioning is accumulating, too. The prefrontal and cingulate cortex, hippocampus and hypothalamus are particularly abundant in vitamin $\mathrm{D}$ receptor and vitamin D activating enzyme; however many other areas contain them to some extent, too (4). Neurosteroid effects of vitamin D likely contribute to the brain development as well as to maintaining the integrity of adult synapses (5). Therefore, relationships between vitamin D deficiency and mental disturbances, particularly those concerning thought and memory processing as well as neuroendocrine axes, seem biologically plausible.

Original clinical studies of observational designs and consequent systematic reviews presented much evidence that there is a significant association between low serum levels of vitamin D and the presence of mental illnesses, particularly depression, schizophrenia and 
dementia $(6-8)$. However, the true nature of the relationship of vitamin D and mental illness is still not completely understood, particularly, knowing that several investigations in various population subgroups in different countries did not support the relationship (9-11). Studies conducted so far which included patients with depression failed to demonstrate clear clinical benefit of active vitamin D supplementation (12). It is not known for sure whether vitamin D deficiency causally affects the mental illness or is confounded with its presence (e.g. inadequate nutrition, physical inactivity, or sun exposure). It is also uncertain what are contributing factors and if, how and to what extent, therapeutic interventions (e.g. drugs) affect vitamin D homeostatic pathways.

The main consequences of vitamin D deficiency are related to bone health. The systematic reviewers of published data indicated that many patients with either depression or schizophrenia could be at risk for bone loss and consequently, fractures $(13,14)$. Researchers proposed several pathogenic mechanisms and the effects of psychotropic drugs could be one of them (15). Hyponatremia is a rare but well-documented adverse effect of both antidepressant and antipsychotic agents while occasional reports revealed the disturbances of some other electrolytes in patients with serious mental conditions including drug-treated ones (16-19). The regulation of vitamin D metabolism is interconnected with homeostatic regulations of bone minerals and certain major electrolytes get indirectly involved in them. More accurate insight into the relationships between those pathways is awaiting novel information.

Contrary to the abundance of published data on this topic in other countries throughout the world, in Serbia, as we are aware, there are no studies on vitamin $\mathrm{D}$ and mental disorders. During the past two decades or more, the residents of Serbia were being exposed to somewhat distinctive stressful experiences resulting in an increase in mental and other health problems among the population, which might have significant impact on public health (20). In addition, extended socioeconomic transition corresponded to high prevalence of other common chronic diseases, which additionally affected community health status in an adverse direction (21). It has been recently demonstrated that markers of nutritional pattern relating to obesity represented a strong predictor for vitamin $\mathrm{D}$ deficiency in patients with chronic, metabolic disease (22). Other researchers in Serbia found that the mean serum concentrations of 25-hydroxyvitamin D were much below the threshold in an apparently healthy (student) population (23). Hence, additional research of those issues in our country is necessary, since it will provide the basis for comparative analysis between societies with different socio-economic backgrounds.

Therefore, the primary aim of our study was to investigate which factors, directly or indirectly connected to mental disorders, were associated with the deficient serum concentrations of vitamin D in comparison with the subjects without these factors, within the large cohort of ambulatory and hospitalized patients suffering from different psychiatric illnesses. The secondary objective was to provide data on the prevalence of vitamin D deficiency among this population group and to compare it with published data relating to other societies. Finally, we aimed to investigate the correlation between the levels of vitamin $\mathrm{D}$ and bone minerals and some major serum electrolytes.

\section{MATERIALS AND METHODS}

Study design. The study had a cross-sectional design and it included patients with a wide range of mental disorders, being treated in everyday psychiatric practice. The study procedures did not incorporate the assessment of mental status (diagnostic and therapeutic procedures of mental illness); necessary data were obtained from medical records. The study primary followed the observational approach because the only interventional procedures were related to blood sampling in order to measure vitamin D and other study analytes. In general, the study design adhered to similar approaches already used by other researchers in the field $(24,25)$. The study conduction complied with the code of ethics of the World Medical Association (Declaration of Helsinki) and was approved by the Ethics Board of the Clinical Centre "Kragujevac" and the Ethics Board of Primary Health Care Centre of Kragujevac. The researchers performed the study during the period from May to June 2014, which approximately corresponds to a season with adequate sunshine (late spring, early summer).

Study population. The inclusion criteria were: adult patients (18 y of age or more), male or female gender, treated at the Clinic for Psychiatry of the Clinical Centre "Kragujevac" (outpatients and inpatients) or Department of Neuropsychiatry of the Primary Health Care Centre (outpatients), Kragujevac, Serbia, who had a mental disorder at the onset (first episode) or stable chronic disease or exacerbation phase (relapse) of chronic diseases, and had given consent for voluntary participation in the study. According to International Statistical Classification of Diseases and Related Health Problems, 10th Revision, of the World Health Organization, diagnostic codes were as follows: organic, including symptomatic, mental disorders (F00-F09), mental and behavioral disorders due to psychoactive substance use (F10-F19), schizophrenia, schizotypal and delusional disorders (F20-F29), mood disorders (F30-F39), neurotic, stress-related and somatoform disorders (F40F48), behavioural syndromes associated with physiological disturbances and physical factors (F50-F59), disorders of adult personality and behaviour (F60F69), mental retardation (F70-F79), disorders of psychological development (F80-F89) and behavioural and emotional disorders with onset usually occurring in childhood and adolescence (F90-F98) (http://apps. who.int/classifications/icd10/browse/2015/en). The following subjects were excluded from participation: people with any medically documented somatic disease that disturbed homeostasis of bone and related minerals and hormones including vitamin D, those with an ill- 
ness that prevented study conduction (unable to care for themselves or requiring the equivalent of institutional or hospital care or suffering from a disease that was progressing rapidly) and subjects that refused to participate in the study. All subjects lived in a single, narrow geographical area-the territory of the city of Kragujevac and surrounding area-and had the same ethnicity (Serbian) and the skin pigmentation type of Fitzpatrick II (about one-fourth of the patients) or III (about threefourths of the patients).

Data collection, study procedures and vitamin D status. The patients were screened for eligibility from among the overall population of patients with mental disorders being treated at the clinic and the department. The investigators scheduled successive visits randomly, at their own discretion, because no prespecified pattern was defined. Only one visit per patient was planned. Every patient being hospitalized or attending the outpatient facility during his or her regular psychiatric care program at the time of the study visit was asked for assessment of eligibility to be included in the study. During this time the researchers retrieved medical records, explained the study to the patient, performed the preliminary interview and if inclusion criteria were met (having no exclusion conditions), obtained subject's informed consent. Then, the researcher interviewed the patient in more detail, for additional data relating to the study variables.

The semi-structured questionnaire designed for assessment of vitamin D status was based on previous studies concerning the topic and conducted in the same geographical area $(26,27)$. That original questionnaire was modified and supplemented for additional variables of interest, taking into account the following: a) the questionnaires for assessment of demographic, socio-economic, nutritional and life-style habits of the country's population, used by the national public health authority (28); b) the guidelines for the assessment of status, protective and risk factors for bone and vitamin D metabolism (29, 30); and c) general methodological principles (31). The final format of the study questionnaire consisted of variables classified into several topics that related to: demographic characteristics, previous medical personal and family history, current psychiatric and, if appropriate, somatic illness, as well as dietary and living habits representing the known risk factors for vitamin D deficiency and/or bone metabolic diseases (e.g. low-calcium intake, inadequate sun exposure, physical inactivity, smoking, alcohol, drug-induced osteoporosis), and information on drugs and substance abuse.

Blood sampling was performed during the visit (one sample per patient) according to common standards in clinical biochemistry. Samples were collected and centrifuged immediately. The serum was stored in the freezer (at $-30^{\circ} \mathrm{C}$ ) until determination of the biochemical parameters (usually within a week from date of sampling) in the Biochemistry Department of the hospital.

Serum concentration of vitamin D, in the form of 25-hydroxyvitamin D [25(OH)D], calcium, phosphorus, magnesium, sodium and potassium were mea- sured using a Cobas e601 analyzer (Roche Diagnostics, Mannheim, Germany) and Beckman Coulter AU 680 biochemical analyzers, as appropriate. Vitamin D measurements were performed using the manufacturer's reagent testing kit for the electrochemiluminescence binding assay (vitamin D total), providing the quality control measures which included regular internal and external controls according to the laboratory quality assurance procedures.

The primary dependent variable was the frequency of vitamin D status types defined by cut-off serum concentration as deficiency $(<12 \mathrm{ng} / \mathrm{mL})$, inadequacy $(12-20 \mathrm{ng} / \mathrm{mL})$, or sufficiency $(>20 \mathrm{ng} / \mathrm{mL})(32)$. The higher value ranges were also considered in supplementary analysis because some professional and scientific authorities recommended the cut-off value of $30 \mathrm{ng} /$ $\mathrm{mL}$ as the level of vitamin D sufficiency status (30, 33). The toxic range was defined as values $>150 \mathrm{ng} /$ $\mathrm{mL}$ (34). Different variables were identified as independent or confounding factors for vitamin D status such as psychotropic drugs or somatic comorbidities connected with osteoporosis $(35,36)$. In addition, we measured serum concentration of ions of calcium (total), phosphorus and magnesium (secondary outcome variables), as well as sodium and potassium (confounding variables). Determination of serum electrolytes was based on well-known facts about direct and indirect connections to their metabolism, mutually and with the homeostasis of vitamin D (37-39) as well as the influence of psychotropic drugs $(16,17,40)$.

Statistical analysis. We estimated sample size based on recent research investigating the status of vitamin $\mathrm{D}$ in patients with psychotic disorders in the same geographic area (26). The mean vitamin D serum concentration, measured as $25(\mathrm{OH}) \mathrm{D}$, in that study population was $22.26 \mathrm{ng} / \mathrm{mL}$ and the standard deviation was $8.97 \mathrm{ng} / \mathrm{mL}$. We proposed that a putative factor (a study variable), being the risk for vitamin $\mathrm{D}$ deficiency would decrease 25(OH)D concentrations for at least 20\% (targetting the range of insufficient levels), in the exposed patients cohort (in whom a study variable was present) compared to the unexposed subjects in our study cohort (in whom a study variable was absent). Taking into account the above-mentioned data, an alpha of 0.05 , a study power of 0.8 and a two-sided test between two independent groups with a ratio of the exposed and the unexposed of $1: 3$, we calculated a total sample size of 220 patients.

Statistical analyses of collected data included testing of sample distribution for normality with graphs (Normal Q-Q Plot and Histogram) and tests (KolmogorovSmirnov and Shapiro-Wilk). The measures of descriptive statistics (frequencies, percentages, mean, median, standard deviation [SD] and range) were used for parameters description. The Fisher exact test was applied for testing the differences between groups (deficiency, insufficiency, sufficiency and toxicity levels of $25(\mathrm{OH}) \mathrm{D})$, along with the Wilcoxon rank sum test and Pearson $\chi^{2}$ test. In order to identify the risks independently associated with vitamin D deficiency we used a multivariable binary logistic 
Table 1. Demographic characteristics of patients according to 25(OH)D categories.

\begin{tabular}{|c|c|c|c|c|}
\hline \multirow[b]{2}{*}{ Variable } & \multirow[b]{2}{*}{ Total } & \multicolumn{2}{|c|}{$25(\mathrm{OH}) \mathrm{D}$ status } & \multirow[b]{2}{*}{ Statistics } \\
\hline & & $\begin{array}{l}\text { Deficient } \\
<12 \mathrm{ng} / \mathrm{mL}\end{array}$ & $\begin{array}{l}\text { Non-deficient } \\
>12 \mathrm{ng} / \mathrm{mL}\end{array}$ & \\
\hline \multicolumn{5}{|l|}{ General } \\
\hline \multicolumn{5}{|l|}{ Gender } \\
\hline Male & $72(33 \%)$ & $36(26 \%)$ & $36(60 \%)$ & \multirow{2}{*}{$\begin{array}{l}\text { Pearson } \chi^{2} \text { test } \\
\chi^{2}{ }_{1}=9, p=0.003\end{array}$} \\
\hline Female & $148(67 \%)$ & $104(74 \%)$ & $44(40 \%)$ & \\
\hline \multicolumn{5}{|l|}{ Age $(y)$} \\
\hline Mean (SD) & $49(13)$ & $50(14)$ & $47(13)$ & \multirow{2}{*}{$\begin{array}{l}\text { Wilcoxon rank sum test } \\
W=6,007, p=0.37\end{array}$} \\
\hline Median (range) & $49(19-81)$ & $49(21-81)$ & $49(19-71)$ & \\
\hline \multicolumn{5}{|l|}{ Body mass index $\left(\mathrm{kg} / \mathrm{m}^{2}\right)$} \\
\hline Mean (SD) & $25(5)$ & $25(5)$ & $25(4)$ & \multirow{2}{*}{$\begin{array}{l}\text { Wilcoxon rank sum test } \\
W=5,063, p=0.77\end{array}$} \\
\hline Median (range) & $25(16-40)$ & $25(16-40)$ & $25(17-36)$ & \\
\hline \multicolumn{5}{|c|}{ Education and conditions of life } \\
\hline Education & & & & \\
\hline Elementary & $58(26 \%)$ & $38(27 \%)$ & $20(25 \%)$ & \multirow{3}{*}{$\begin{array}{l}\text { Pearson } \chi^{2} \text { test } \\
\chi^{2}{ }_{1}=9, p=0.56\end{array}$} \\
\hline Secondary & $140(64 \%)$ & $86(61 \%)$ & $54(68 \%)$ & \\
\hline Tertiary & $22(10 \%)$ & $16(11 \%)$ & $6(7 \%)$ & \\
\hline \multicolumn{5}{|l|}{ Inhabitancy status } \\
\hline Urban & $175(80 \%)$ & $114(81 \%)$ & $61(76 \%)$ & \multirow{3}{*}{$\begin{array}{l}\text { Pearson } \chi^{2} \text { test } \\
\chi^{2}{ }_{1}=1, p=0.31\end{array}$} \\
\hline Rural & $44(20 \%)$ & $25(18 \%)$ & $19(24 \%)$ & \\
\hline Not applicable & $1(0 \%)$ & $1(1 \%)$ & $0(0 \%)$ & \\
\hline \multicolumn{5}{|l|}{ Life conditions } \\
\hline Good & $61(28 \%)$ & $34(24 \%)$ & $27(34 \%)$ & \multirow{5}{*}{$\begin{array}{l}\text { Pearson } \chi^{2} \text { test } \\
\chi^{2}{ }_{2}=2, p=0.32\end{array}$} \\
\hline Average & $75(34 \%)$ & $50(36 \%)$ & $25(31 \%)$ & \\
\hline Poor & $81(37 \%)$ & $54(39 \%)$ & $27(34 \%)$ & \\
\hline Not applicable & $3(1 \%)$ & $2(1 \%)$ & $1(1 \%)$ & \\
\hline Total number of subjects & $220(100 \%)$ & $140(100 \%)$ & $80(100 \%)$ & \\
\hline
\end{tabular}

regression model. The study population was divided in two subgroups, according to the presence of vitamin D deficiency. Then, we tested the association of vitamin D deficiency for various proposed risk factors, grouped into the following categories: demographics, life style habits (e.g. diet, sun exposure, exercise, smoking), drug use, comorbid disorders (somatic diseases), type of the mental illness and current status of musculoskeletal system (presence of documented muscle disease or osteoporosis or other metabolic bone disease or data about previous spontaneous bone fractures). The variables, which were statistically significantly associated with the primary outcome at univariable analysis, were considered for selection into the multivariable model whose output gave independent associations as a final result. The Spearman rank correlation test was used to evaluate the correlation between $25(\mathrm{OH}) \mathrm{D}$ and other numeric variables of interest, and linear regression was used for a model of their relationship. The level of probability for statistical significance was established at $p<0.05$. Data processing and analysis were done in the statistical program R-version 3.1.1 (2014-07-10) — "Sock it to Me" Copyright (C) 2014 The R Foundation for Statistical Computing (taken over: 22nd of October 2014).

\section{RESULTS}

The study included 220 patients with different types of mental disorders with a participation rate above $90 \%$ of all screened subjects. For 41 patients $(19 \%)$ it was the first episode of disease, 100 patients (45\%) had a stable disease and 79 patients (36\%) had a relapsing episode of mental illness. The mean value of vitamin D (standard deviation) in the whole group of study subjects was 12 (8) ng/mL (median 10, min 3, max 59). One hundred forty patients $(64 \%)$ had a deficiency of vitamin D $(25(\mathrm{OH}) \mathrm{D}<12 \mathrm{ng} / \mathrm{mL})$, with the mean serum concentration of 7 (3) ng/mL (median 7, min 3, max 12). Forty-five patients $(20 \%)$ had an inadequacy of vitamin $\mathrm{D}(25(\mathrm{OH}) \mathrm{D} 12-20 \mathrm{ng} / \mathrm{mL})$, with the mean serum concentrations of 15 (2) ng/mL (median 15, min 12, max $20)$. Only 35 patients (16\%) had serum concentrations of $25(\mathrm{OH}) \mathrm{D}>20 \mathrm{ng} / \mathrm{mL}$ with the mean value of $27(8)$ $\mathrm{ng} / \mathrm{mL}$ (median 25, min 20, $\max 59$ ). Among them, 26 patients had vitamin $\mathrm{D}$ serum concentration within the range of $>20-30 \mathrm{ng} / \mathrm{mL}$, with the mean of 24 (3) $\mathrm{ng} /$ $\mathrm{mL}$ (median 22, min 20, max 29) and 9 patients had vitamin D serum concentration $>30 \mathrm{ng} / \mathrm{mL}$ with the mean serum value of 37 (9) ng/mL (median 35, min 30, max 59). There were no subjects with serum concentration of vitamin $\mathrm{D}$ within a toxic range $(25(\mathrm{OH}) \mathrm{D}$ $>150 \mathrm{ng} / \mathrm{mL})$.

In total, 12 variables showed significantly different distribution between the two groups (gender, physical activity, exercising, spending a majority of day in bed, offal in the diet, bread in the diet, sun exposure, spending much time outdoors, COPD, clozapine use, calcium 
Table 2. Patient's lifestyle according to 25(OH)D categories.

\begin{tabular}{|c|c|c|c|c|}
\hline \multirow[b]{2}{*}{ Variable } & \multirow[b]{2}{*}{ Total } & \multicolumn{2}{|c|}{$25(\mathrm{OH}) \mathrm{D}$ status } & \multirow[b]{2}{*}{ Statistics } \\
\hline & & $\begin{array}{c}\text { Deficient } \\
<12 \mathrm{ng} / \mathrm{mL}\end{array}$ & $\begin{array}{l}\text { Non-deficient } \\
>12 \mathrm{ng} / \mathrm{mL}\end{array}$ & \\
\hline \multicolumn{5}{|l|}{ Lifestyle } \\
\hline \multicolumn{5}{|l|}{ Smoking } \\
\hline Yes & $122(55 \%)$ & $72(51 \%)$ & $50(63 \%)$ & \multirow{4}{*}{$\begin{array}{l}\text { Pearson } \chi^{2} \text { test } \\
\chi^{2}{ }_{2}=4, p=0.13\end{array}$} \\
\hline No & $87(40 \%)$ & $62(44 \%)$ & $25(31 \%)$ & \\
\hline Earlier & $10(5 \%)$ & $5(4 \%)$ & $5(6 \%)$ & \\
\hline Not applicable & $1(1 \%)$ & $0(0 \%)$ & $1(0 \%)$ & \\
\hline \multicolumn{5}{|l|}{ Physical activity } \\
\hline Yes & $150(68 \%)$ & $88(63 \%)$ & $62(78 \%)$ & \multirow{2}{*}{$\begin{array}{l}\text { Pearson } \chi^{2} \text { test } \\
\chi^{2}{ }_{1}=5, p=0.02\end{array}$} \\
\hline No & $70(32 \%)$ & $52(37 \%)$ & $18(23 \%)$ & \\
\hline \multicolumn{5}{|l|}{ Exercising (weekly) } \\
\hline Yes & $14(6 \%)$ & $4(3 \%)$ & $10(13 \%)$ & \multirow{2}{*}{$\begin{array}{l}\text { Fisher exact test } \\
p=0.007\end{array}$} \\
\hline No & $206(94 \%)$ & $136(97 \%)$ & $70(88 \%)$ & \\
\hline \multicolumn{5}{|c|}{ Spending majority of day in bed } \\
\hline Yes & $101(46 \%)$ & $72(51 \%)$ & $29(36 \%)$ & \multirow{2}{*}{$\begin{array}{l}\text { Pearson } \chi^{2} \text { test } \\
\chi^{2}{ }_{1}=5, p=0.03\end{array}$} \\
\hline No & $119(54 \%)$ & $68(49 \%)$ & $51(64 \%)$ & \\
\hline \multicolumn{5}{|c|}{ Offal in the diet (how many times per month) } \\
\hline Mean (SD) & $2(2)$ & $2(2)$ & $3(2)$ & \multirow{2}{*}{$\begin{array}{l}\text { Wilcoxon rank sum tes } \\
W=616, p=0.01\end{array}$} \\
\hline Median (range) & $2(1-10)$ & $1(1-8)$ & $2(1-10)$ & \\
\hline \multicolumn{5}{|c|}{ Bread in the diet (the quantity of bread per day) } \\
\hline Mean (SD) & $288(171)$ & $255(146)$ & $344(195)$ & \multirow{2}{*}{$\begin{array}{l}\text { Wilcoxon rank sum test } \\
W=3,677, p=0.004\end{array}$} \\
\hline Median (range) & $225(50-750)$ & $200(50-600)$ & $300(50-750)$ & \\
\hline \multicolumn{5}{|l|}{ Sun exposure, the last year } \\
\hline Yes & $128(58 \%)$ & $71(51 \%)$ & $57(71 \%)$ & \multirow{2}{*}{$\begin{array}{l}\text { Pearson } \chi^{2} \text { test } \\
\chi^{2}{ }_{1}=9, p=0.002\end{array}$} \\
\hline No & $92(42 \%)$ & $69(49 \%)$ & $23(29 \%)$ & \\
\hline \multicolumn{5}{|l|}{ Sun exposure, the last week } \\
\hline$<5 \mathrm{~min} / \mathrm{d}$ & $76(35 \%)$ & $55(39 \%)$ & $21(26 \%)$ & \multirow{4}{*}{$\begin{array}{l}\text { Fisher exact test } \\
p=0.002\end{array}$} \\
\hline $5-15 \mathrm{~min} / \mathrm{d}$ & $6(3 \%)$ & $4(3 \%)$ & $2(3 \%)$ & \\
\hline $15-30 \mathrm{~min} / \mathrm{d}$ & $44(20 \%)$ & $34(24 \%)$ & $10(13 \%)$ & \\
\hline$>30 \mathrm{~min} / \mathrm{d}$ & $94(43 \%)$ & $44(34 \%)$ & $47(59 \%)$ & \\
\hline \multicolumn{5}{|l|}{ Spending much time outdoors } \\
\hline Yes & $75(34 \%)$ & $37(26 \%)$ & $38(48 \%)$ & \multirow{4}{*}{$\begin{array}{l}\text { Pearson } \chi^{2} \text { test } \\
\chi^{2}{ }_{1}=10, p=0.001\end{array}$} \\
\hline No & $144(65.45 \%)$ & $102(72.86 \%)$ & $42(52.5 \%)$ & \\
\hline Not applicable & $1(0 \%)$ & $1(1 \%)$ & $0(0 \%)$ & \\
\hline Total number of subjects & $220(100 \%)$ & $140(100 \%)$ & $80(100 \%)$ & \\
\hline
\end{tabular}

channel blockers use, and sodium). There were no significant differences in the prevalence of any other medically-controlled, stable comorbid conditions between study groups, including arterial hypertension (found in a total of 66 subjects, 30\%), diabetes mellitus (16, 7\%), gastritis $(14,6 \%)$, osteoporosis $(12,5 \%)$ and additional, sporadically-appearing illnesses (documented in a total of 11 subjects, 5\%). The details about the main variables that we analyzed in the study are shown in Tables 1-4. Among them, eight variables had been considered clinically meaningful (gender, physical activity, exercising, spending a majority of day in bed, offal in the diet, sun exposure, COPD, and clozapine use) and they were selected for a multivariable, binary logistic regression model in order to identify possible independent predictors for vitamin D deficiency. Two variables (female gender and clozapine use) were significantly associated as risk factors $(p<0.05)$ and four variables (physical activity, exercising, offal in the diet, and chronic obstructive pulmonary disease) were associated as protective factors $(p<0.05)$ for vitamin D deficiency (Table 5). For two variables entered in the model, spending a majority of the day in bed $(p=0.27)$ and sun exposure (during the last year) $(p=0.08)$, the associations were not statistically significant, suggesting them to be confounders. In addition, in the females and the users of clozapine the mean vitamin D serum concentrations were $>20 \%$ less than the mean values of vitamin $\mathrm{D}$ in the males and the non-users of clozapine, respectively. Serum concentrations of $25(\mathrm{OH}) \mathrm{D}$ were significantly correlated with serum concentrations of calcium $(\varrho=0.15, p=0.02)$, phosphorous $(\varrho=0.15, p=0.02)$, magnesium $(\varrho=0.15$, $p=0.03)$ and sodium $(\varrho=0.18, p=0.01)$ but not with potassium $(\varrho=0.13, p=0.06)(\varrho$, Spearman's rank correlation; $p$, probability). The correlations of serum concentration of $25(\mathrm{OH}) \mathrm{D}$ with serum concentration of calcium (Fig. 1), phosphorous (Fig. 2), magnesium (Fig. 3) and sodium (Fig. 4) had moderate positive and linear 
Table 3. Mental and other disorders, psychotropic and other drugs of patients according to 25(OH)D categories.

\begin{tabular}{|c|c|c|c|c|}
\hline \multirow[b]{2}{*}{ Variable } & \multirow[b]{2}{*}{ Total } & \multicolumn{2}{|c|}{$25(\mathrm{OH}) \mathrm{D}$ status } & \multirow[b]{2}{*}{ Statistics } \\
\hline & & $\begin{array}{l}\text { Deficient } \\
<12 \mathrm{ng} / \mathrm{mL}\end{array}$ & $\begin{array}{l}\text { Non-deficient } \\
>12 \mathrm{ng} / \mathrm{mL}\end{array}$ & \\
\hline \multicolumn{5}{|l|}{ Mental disorders (ICD-10) ${ }^{1}$} \\
\hline F00-F09 & $18(8 \%)$ & $15(11 \%)$ & $3(4 \%)$ & $\begin{array}{l}\text { Fisher exact test } \\
p=0.07\end{array}$ \\
\hline F10-F19 & $20(9 \%)$ & $12(9 \%)$ & $8(10 \%)$ & $\begin{array}{l}\text { Pearson } \chi^{2} \text { test } \\
\chi^{2}{ }_{1}=0, p=0.72\end{array}$ \\
\hline F20-F29 & $81(37 \%)$ & $52(37 \%)$ & $29(36 \%)$ & $\begin{array}{l}\text { Pearson } \chi^{2} \text { test } \\
\chi^{2}{ }_{1}=0, p=0.89\end{array}$ \\
\hline F30-F39 & $116(53 \%)$ & $74(53 \%)$ & $42(53 \%)$ & $\begin{array}{l}\text { Pearson } \chi^{2} \text { test } \\
\chi^{2}{ }_{1}=0, p=0.96\end{array}$ \\
\hline F40-F48 & $27(12 \%)$ & $14(10 \%)$ & $13(16 \%)$ & $\begin{array}{l}\text { Pearson } \chi^{2} \text { test } \\
\chi^{2}{ }_{1}=2, p=0.17\end{array}$ \\
\hline F50-F59 & $1(0 \%)$ & $1(1 \%)$ & $0(0 \%)$ & $\begin{array}{l}\text { Fisher exact test } \\
p=1\end{array}$ \\
\hline F60-F69 & $8(4 \%)$ & $8(6 \%)$ & $0(0 \%)$ & $\begin{array}{l}\text { Fisher exact test } \\
p=0.05\end{array}$ \\
\hline F70-F79 & $7(3 \%)$ & $7(5 \%)$ & $0(0 \%)$ & $\begin{array}{l}\text { Fisher exact test } \\
p=0.05\end{array}$ \\
\hline F80-F89 & $2(1 \%)$ & $2(1 \%)$ & $0(0 \%)$ & $\begin{array}{l}\text { Fisher exact test } \\
p=0.54\end{array}$ \\
\hline $\mathrm{T} 42$ & $2(1 \%)$ & $0(0 \%)$ & $2(3 \%)$ & $\begin{array}{l}\text { Fisher exact test } \\
p=0.13\end{array}$ \\
\hline G40 & $7(3 \%)$ & $4(3 \%)$ & $3(4 \%)$ & $\begin{array}{l}\text { Fisher exact test } \\
p=0.71\end{array}$ \\
\hline \multicolumn{5}{|l|}{ Mental disorder duration (y) } \\
\hline Mean (SD) & $7(8)$ & $7(8)$ & $7(8)$ & Wilcoxon rank sum test \\
\hline Median (range) & $4(0-35)$ & $5(0-33)$ & $3(0-35)$ & $\mathrm{W}=5,362, p=0.59$ \\
\hline \multicolumn{5}{|l|}{ Treatment status } \\
\hline Inpatient & $88(40 \%)$ & $61(44 \%)$ & $27(34 \%)$ & Pearson $\chi^{2}$ test \\
\hline Outpatient & $132(60 \%)$ & $79(56 \%)$ & $53(66 \%)$ & $\chi_{2}^{2}=2, p=0.15$ \\
\hline \multicolumn{5}{|l|}{ Other diseases $^{2}$} \\
\hline COPD & $10(5 \%)$ & $3(2 \%)$ & $7(9 \%)$ & $\begin{array}{l}\text { Fisher exact test } \\
p=0.04\end{array}$ \\
\hline \multicolumn{5}{|l|}{ Psychotropic drugs $^{3}$} \\
\hline Antipsychotics & $110(50 \%)$ & $71(51 \%)$ & $39(49 \%)$ & $\begin{array}{l}\text { Pearson } \chi^{2} \text { test } \\
\chi^{2}{ }_{1}=0, p=0.85\end{array}$ \\
\hline Clozapine & $15(7 \%)$ & $14(10 \%)$ & $1(1 \%)$ & $\begin{array}{l}\text { Fisher exact test } \\
p=0.01\end{array}$ \\
\hline Antidepressants & $129(59 \%)$ & $83(59 \%)$ & $46(58 \%)$ & $\begin{array}{l}\text { Pearson } \chi^{2} \text { test } \\
\chi^{2}{ }_{1}=0, p=0.88\end{array}$ \\
\hline Sedative-anxiolytics & $158(72 \%)$ & $99(71 \%)$ & $59(74 \%)$ & $\begin{array}{l}\text { Pearson } \chi^{2} \text { test } \\
\chi^{2}{ }_{1}=0, p=0.53\end{array}$ \\
\hline Mood stabilizers & $92(42 \%)$ & $63(45 \%)$ & $29(36 \%)$ & $\begin{array}{l}\text { Pearson } \chi^{2} \text { test } \\
\chi^{2}{ }_{1}=1, p=0.23\end{array}$ \\
\hline Calcium channel blockers & $13(6 \%)$ & $12(9 \%)$ & $1(1 \%)$ & $\begin{array}{l}\text { Fisher exact test } \\
p=0.03\end{array}$ \\
\hline Total number of subjects & $220(100 \%)$ & $140(100 \%)$ & $80(100 \%)$ & \\
\hline
\end{tabular}

${ }^{1}$ See text for explanation of diagnostic codes (due to comorbidities the sum of all diagnostic entities exceeds the number of study patients); T42, poisoning by antiepileptic, sedative-hypnotic and antiparkinsonism drugs (reconvalescent phase); and G40, epilepsy appeared as comorbidities, too.

${ }^{2}$ The most important and statistically significant variables are presented.

${ }^{3}$ The numbers totaled beyond study sample due to comorbid symptoms/diagnoses. 
Table 4. Serum electrolytes of patients according to $25(\mathrm{OH}) \mathrm{D}$ categories.

\begin{tabular}{|c|c|c|c|c|}
\hline \multirow[b]{2}{*}{ Variable } & \multirow[b]{2}{*}{ Total } & \multicolumn{2}{|c|}{$25(\mathrm{OH}) \mathrm{D}$ status } & \multirow[b]{2}{*}{ Statistics } \\
\hline & & $\begin{array}{l}\text { Deficient } \\
<12 \mathrm{ng} / \mathrm{mL}\end{array}$ & $\begin{array}{l}\text { Non-deficient } \\
>12 \mathrm{ng} / \mathrm{mL}\end{array}$ & \\
\hline \multicolumn{5}{|l|}{ Calcium (mmol/L) } \\
\hline Mean (SD) & $2.36(0.24)$ & $2.34(0.28)$ & $2.41(0.15)$ & \multirow{2}{*}{$\begin{array}{l}\text { Wilcoxon rank sum test } \\
W=4,774, p=0.17\end{array}$} \\
\hline Median (range) & $2.39(0.82-2.96)$ & $2.39(0.82-2.96)$ & $2.40(1.89-2.8)$ & \\
\hline \multicolumn{5}{|l|}{ Magnesium (mmol/L) } \\
\hline Mean (SD) & $0.79(0.15)$ & $0.78(0.18)$ & $0.8(0.1)$ & \multirow{2}{*}{$\begin{array}{l}\text { Wilcoxon rank sum test } \\
W=4,412, p=0.08\end{array}$} \\
\hline Median (range) & $0.78(0.40-2.49)$ & $0.77(0.40-2.49)$ & $0.79(0.55-1.2)$ & \\
\hline \multicolumn{5}{|l|}{ Phosphorous (mmol/L) } \\
\hline Mean (SD) & $1.08(0.23)$ & $1.07(0.24)$ & $1.1(0.21)$ & \multirow{2}{*}{$\begin{array}{l}\text { Wilcoxon rank sum test } \\
W=4,740, p=0.35\end{array}$} \\
\hline Median (range) & $1.06(0.33-1.91)$ & $1.06(0.33-1.91)$ & $1.08(0.71-1.6)$ & \\
\hline \multicolumn{5}{|l|}{ Sodium $(\mathrm{mmol} / \mathrm{L})$} \\
\hline Mean (SD) & $140(5)$ & $140(5)$ & $141(4)$ & \multirow{2}{*}{$\begin{array}{l}\text { Wilcoxon rank sum test } \\
W=3,884, p=0.03\end{array}$} \\
\hline Median (range) & $140(110-156)$ & $140(110-153)$ & $141(126-156)$ & \\
\hline \multicolumn{5}{|l|}{ Potassium (mmol/L) } \\
\hline Mean (SD) & $4.4(0.5)$ & $4.4(0.5)$ & $4.5(0.5)$ & \multirow{3}{*}{$\begin{array}{l}\text { Wilcoxon rank sum test } \\
W=4,245, p=0.19\end{array}$} \\
\hline Median (range) & $4.4(3.3-6.0)$ & $4.4(3.3-6.0)$ & $4.4(3.6-5.7)$ & \\
\hline Total number of subjects & $220(100 \%)$ & $140(100 \%)$ & $80(100 \%)$ & \\
\hline
\end{tabular}

Table 5. The factors independently associated with vitamin D deficiency $(25(\mathrm{OH}) \mathrm{D}<12 \mathrm{ng} / \mathrm{mL})$ in the model of multivariable binary logistic regression.

\begin{tabular}{lrcl}
\hline \multicolumn{1}{c}{ Variables } & OR & $95 \% \mathrm{CI}$ & $p$ \\
\hline Female gender & 2.5 & $1.3-4.9$ & 0.006 \\
Physical activity & 0.4 & $0.2-0.9$ & 0.02 \\
Exercising & 0.2 & $<0.1-0.7$ & 0.02 \\
Offal in the diet & 0.5 & $0.3-0.9$ & 0.03 \\
COPD & 0.1 & $<0.1-0.4$ & 0.004 \\
Clozapine & 15.6 & $1.7-144.7$ & 0.02 \\
\hline
\end{tabular}

OR, odds ratio; CI, confidence interval; $p$, probability (Wald test); COPD, chronic obstructive pulmonary disease.

relationships.

\section{DISCUSSION}

In the present study we reported significant relationships between the existence of vitamin D deficiency and the presence of two proposed risks and three anticipated protectors for decreased vitamin D serum concentrations. In addition, we explored vitamin D status in patients with mental disorders, finding a very high prevalence of deficiency and insufficiency ranges. Finally, we found small but detectable associations between serum levels of vitamin D and calcium, phosphorous, magnesium and sodium. This approach had rarely been used in previous studies in the field of psychiatry and similar data in this subpopulation were, generally, scarce.

Our study provides evidence that in patients with mental disorders the female gender factor and a treatment-related factor (clozapine use) were independently associated with vitamin D deficiency. On the other side, some lifestyle and dietary patterns (physical activity,

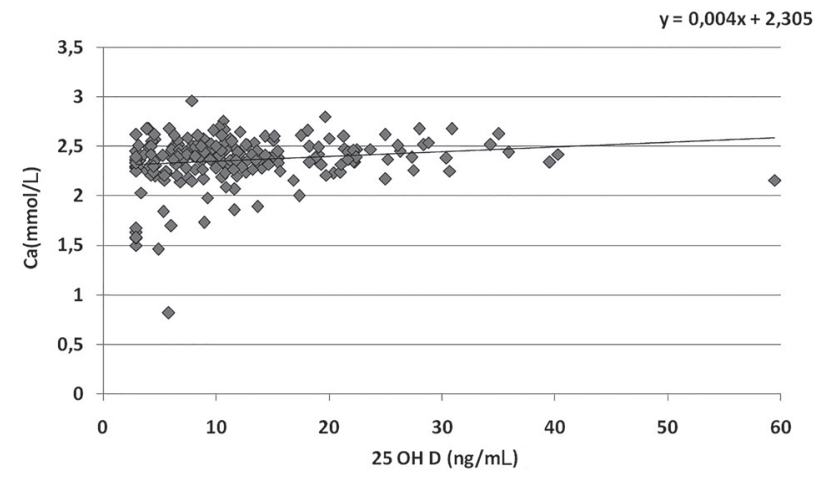

Fig. 1. Correlation of vitamin D, in the form of $25(\mathrm{OH})$ $\mathrm{D}$, and calcium serum concentrations.

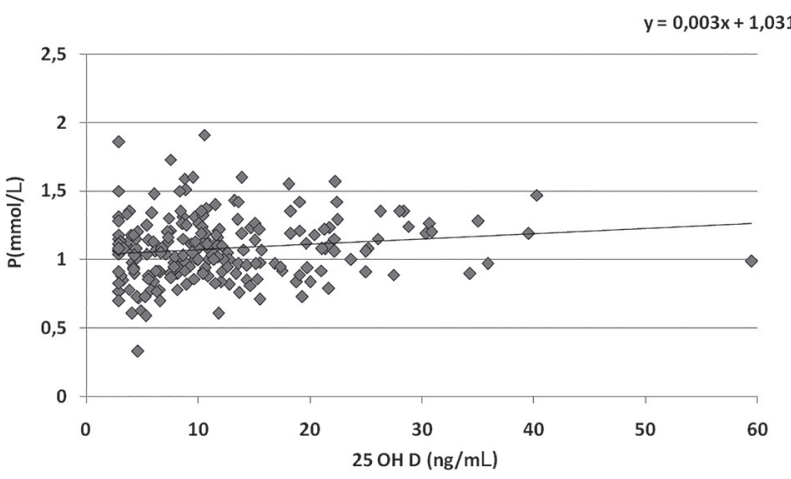

Fig. 2. Correlation of vitamin D, in the form of $25(\mathrm{OH})$

D, and phosphorous serum concentrations.

exercising, and offal in the diet) and comorbid conditions (chronic obstructive pulmonary disease: COPD) significantly and independently aggregated in the patients who had $25(\mathrm{OH}) \mathrm{D}$ serum concentrations above the deficiency cut-off level. 


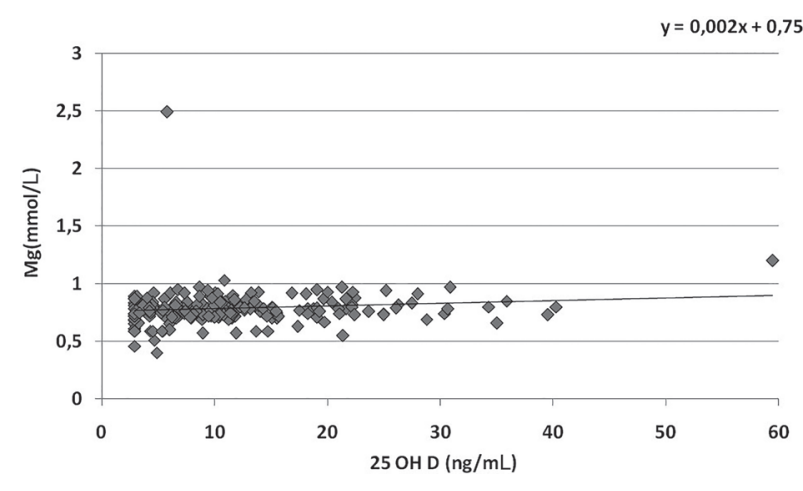

Fig. 3. Correlation of vitamin D, in the form of $25(\mathrm{OH})$ $\mathrm{D}$, and magnesium serum concentrations.

It is well documented that female gender represents a risk for disturbances of homeostasis of bone minerals and hormones, predisposing women to the osteoporosis-related events (41). The researchers also found that females had a higher prevalence of both vitamin D deficiency and vitamin D insufficiency in comparison with males of the same population (42). Abundant fat tissue and limited muscle mass in women as well as pregnancy-related issues are likely contributors to the observed gender differences (43-45). On the other hand, healthy life-styles (appropriate physical activity) and diet with sufficient nutrients (offal is a vitamin Drich food) represent recognized protective factors in this regard (35). The lack of a diet rich in vitamin D content (e.g. meat, eggs, fish) and of sufficient exposure to sunlight (at least 5-15 min to create 1,000-2,000 IU of vitamin D) are common and already reported habitual patterns in patients with psychiatric disorders, which agrees with our findings (43, 46-48).

On the other hand, there is little published evidence directly connecting clozapine and vitamin D. At the present state of knowledge, we propose that use of clozapine is rather an independent marker of severity of mental illness than the major cause of vitamin $\mathrm{D}$ deficiency. Indeed, inadequate neurosteroid action of vitamin $\mathrm{D}$ on the brain, particularly during development, is related to the changes such as inflammatory and immunological disturbances, which are present in schizophrenia, too $(49,50)$. Therefore, the cases of very low serum levels of $25(\mathrm{OH}) \mathrm{D}$ in our study probably point to patients with serious mental disorders that required the prescription of clozapine, the first line option for treatment-resistant psychotic features. Our finding about COPD apparently contradicts many previous reports, which identified this illness as a risk for vitamin D deficiency. It is likely, therefore, that the presence of COPD in subjects in our study has been linked to one or more protective confounders. We conducted our research during the sunshine seasons, the period when the risk in COPD patients is decreased by more than four times (51). Three variables in our study, related to sun exposure significantly, but not independently, were associated with the vitamin D deficiency group. In addition, homeostatic responses to the bone changes induced by acid-base disturbances,

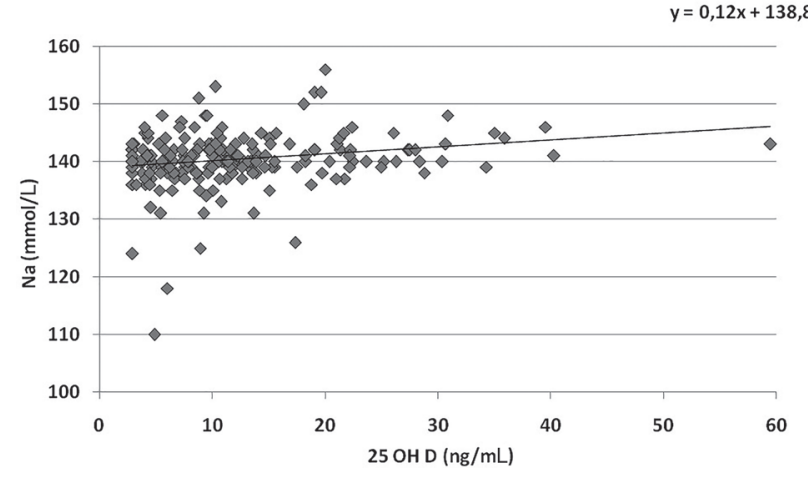

Fig. 4. Correlation of vitamin D, in the form of $25(\mathrm{OH})$ $\mathrm{D}$, and sodium serum concentrations.

commonly associated with COPD exacerbations, interplayed with seasonal oscillations (52).

Our study confirms the findings of earlier research that the presence of mental illness was associated with clinically significant vitamin D deficiency in many patients. For example, within the patients with depression, the prevalence of vitamin D deficiency was, on average, a third higher than in the general population (7). On the other side, the proportion of patients in our study who had the recommended vitamin D serum levels was surprisingly small (about one in eight), classifying our study subjects as a very high-risk group for the development of clinically important hypovitaminosis $\mathrm{D}$ features. The fraction of patients having vitamin Ddeficient serum concentrations in our study was almost two times higher than the one previously reported for the patients from a general practice in a developed country (53). The difference, albeit with smaller magnitude, could be noticed for patients suffering from mental illnesses, too. Compared to our results, in some other societies there were much higher vitamin D serum levels and a lower prevalence of vitamin D deficiency in both in- and outpatients, including those with serious psychotic or depressive disorders (54-56). At present, the reasons for such differences are not completely understood but, at least in part, could be tied to the abovedescribed country's distinctions $(20,21)$. A national policy of mental health care in our country which promoted the implementation of healthy life styles and other preventive medical measures could also improve the vitamin $\mathrm{D}$ status in patients suffering from mental disorders (57). Therefore, the pattern of vitamin D status identified in our study represents a novelty which justifies further, more targeted research about the topic, taking into account the specificities of local environment, too $(21,58)$.

Our results confirmed statistical significance for the positive, moderate correlation of vitamin $\mathrm{D}$ with calcium, phosphorus, magnesium and sodium serum concentrations, which, in the case of the last, has rarely, if ever, been published for patients with mental disorders. Vitamin D is a direct regulator of the metabolism of calcium and, partly, phosphate with feedback relationships encompassing bone, intestine and kidney (36). 
On the other hand, excessive sodium intake represents a recognised risk factor for development of osteoporosis (often associated with vitamin D deficiency) due to interference with the renal excretion of calcium (37). Psychotropic medications by themselves could cause sodium disturbances, primarily hyponatremia (16, 17, 40). Some psychotropics have also been associated with an increased risk for osteoporosis and bone fractures as well as hypocalcemia, either as a drug-class or individual medicines $(15,19,59)$.

Basic studies revealed the link between the activity of vitamin D receptor (VDR) and regulating enzymes (e.g. $1 \alpha$-hydroxylase, 24-hydroxylase) and some phosphate and sodium pathways (e.g. type II sodium-phosphate contransporters). Factors such as targeted dietary interventions and humoral regulators like fibroblast growth factor 23 (FGF23) influence both vitamin D metabolism and some of those pathways, too (60). In addition, paracalcitol, a metabolite of vitamin D, regulates the expression of dozens of genes including mRNA levels of atrial natriuretic factor in animals previously sensitized with a high-salt diet (61). As far as we are aware, researchers have not published similar evidence for humans and therefore, future investigation should focus on putative mechanisms which connect vitamin D, phosphate and sodium regulators, including dietary intake.

Major limitations of our study are the heterogeneity of study subjects and, particularly, the absence of a healthy control group. According to the study aims, we intentionally included a wide range of patients with different mental illnesses and various treatments. This approach diminished sensitivity for identification of risk factors but increased our scope about vitamin D status from an epidemiological point of view. The prevalence of vitamin D deficiency among patients in our study was much higher than in similar studies previously reported (56) which, according to the methodological recommendation for observational studies, required a very large putative control group (at least three times the number of healthy volunteers as patients) (62).

In conclusion, our study revealed that female gender and clozapine use were significantly associated with deficient levels of vitamin D while physical activity, exercising, offal in the diet and chronic obstructive pulmonary disease were associated with sufficient ones. The prevalence of low vitamin D serum levels, either deficient or insufficient, was very high among the patients in our study. Apart from the expected link between serum concentrations of vitamin D and bone minerals, we also found positive correlation with sodium. These findings justify the need for future studies in order to explore exact biological mechanisms, identify all risk and protective factors and establish the public health importance of this issue.

\section{Acknowledgments}

The authors thank the Ministry of Education, Science and Technological Development of the Republic of Serbia, for their support with the research grant 175007 and the Faculty of Medical Science of the University of
Kragujevac for their support with the junior research grant JP 13-14.

\section{REFERENCES}

1) Backovic D. 2010. Mental health and mental hygiene between two millenniums. Med Pregl 63: 833-838.

2) Cashman KD, Dowling KG, Škrabáková Z, GonzalezGross M, Valtueña J, De Henauw S, Moreno L, Damsgaard CT, Michaelsen KF, Mølgaard C, Jorde R, Grimnes G, Moschonis G, Mavrogianni C, Manios Y, Thamm M, Mensink GB, Rabenberg M, Busch MA, Cox L, Meadows S, Goldberg G, Prentice A, Dekker JM, Nijpels G, Pilz S, Swart KM, van Schoor NM, Lips P, Eiriksdottir G, Gudnason V, Cotch MF, Koskinen S, Lamberg-Allardt C, Durazo-Arvizu RA, Sempos CT, Kiely M. 2012. Vitamin D deficiency in Europe: pandemic? Am J Clin Nutr 103: 1033-1044.

3) Quraishi SA, Camargo CA Jr, Manson JE. 2016. Low vitamin D status in Europe: moving from evidence to sound public health policies. Am J Clin Nutr 103: 957-958.

4) Eyles DW, Smith S, Kinobe R, Hewison M, McGrath JJ. 2005. Distribution of the vitamin D receptor and 1 alpha-hydroxylase in human brain. J Chem Neuroanat 29: 21-30.

5) Kesby JP, Eyles DW, Burne TH, McGrath JJ. 2011. The effects of vitamin $\mathrm{D}$ on brain development and adult brain function. Mol Cell Endocrinol 347: 121-127.

6) Anglin RES, Samaan Z, Walter SD, McDonald SD. 2013. Vitamin D deficiency and depression in adults: systematic review and meta-analysis. $\mathrm{Br} J$ Psychiatry 202: 100-107.

7) Valipour G, Saneei P, Esmaillzadeh A. 2014. Serum vitamin D levels in relation to schizophrenia: a systematic review and meta-analysis of observational studies. J Clin Endocrinol Metab 99: 3863-3872.

8) Shen L, Ji HF. 2015. Vitamin D deficiency is associated with increased risk of Alzheimer's disease and dementia: evidence from meta-analysis. Nutr J 14: 76.

9) Zhao G, Ford ES, Li C, Balluz LS. 2010. No associations between serum concentrations of 25-hydroxyvitamin $\mathrm{D}$ and parathyroid hormone and depression among US adults. Br J Nutr 104: 1696-1702.

10) Kwasky AN, Groh CJ. 2012. Vitamin D and depression: is there a relationship in young women? J Am Psychiatr Nurses Assoc 18: 236-243.

11) Pan A, Lu L, Franco OH, Yu Z, Li H, Lin X. 2009. Association between depressive symptoms and 25-hydroxyvitamin D in middle-aged and elderly Chinese. J Affect Disord 118: 240-243.

12) Li G, Mbuagbaw L, Samaan Z, Falavigna M, Zhang S, Adachi JD, Cheng J, Papaioannou A, Thabane L. 2014. Efficacy of vitamin D supplementation in depression in adults: a systematic review. J Clin Endocrinol Metab 99: 757-767.

13) Wu Q, Liu J, Gallegos-Orozco JF, Hentz JG. 2010. Depression, fracture risk, and bone loss: a meta-analysis of cohort studies. Osteoporos Int 21: 1627-1635.

14) Tseng PT, Chen YW, Yeh PY, Tu KY, Cheng YS, Wu CK. 2015. Bone mineral density in schizophrenia: an update of current meta-analysis and literature review under guideline of PRISMA. Medicine (Baltimore) 94: e1967.

15) Rizzoli R, Cooper C, Reginster JY, Abrahamsen B, Adachi JD, Brandi ML, Bruyère O, Compston J, Ducy P, Ferrari S, Harvey NC, Kanis JA, Karsenty G, Laslop A, Rabenda V, Vestergaard P. 2012. Antidepressant medications and 
osteoporosis. Bone 51: 606-613.

16) Leth-Møller KB, Hansen AH, Torstensson M, Andersen SE, Ødum L, Gislasson G, Torp-Pedersen C, Holm EA. 2016. Antidepressants and the risk of hyponatremia: a Danish register-based population study. BMJ Open 6: e011200.

17) Mannesse CK, van Puijenbroek EP, Jansen PA, van Marum RJ, Souverein PC, Egberts TC. 2010. Hyponatraemia as an adverse drug reaction of antipsychotic drugs: a case-control study in Vigibase. Drug Saf 33: 569-578.

18) Lam MH, Chau SW, Wing YK. 2009. High prevalence of hypokalemia in acute psychiatric inpatients. Gen Hosp Psychiatry 31: 262-265.

19) Milovanovic DR, Janjic V, Zornic N, Djukic Dejanovic S, Jankovic SM. 2010. Risperidone-associated hypocalcemia. Am J Psychiatry 167: 1533-1534.

20) Tosevski DL, Gajic SD, Milovancevic MP. 2012. State of psychiatry in Serbia-problems, advances and perspectives. Int Rev Psychiatry 24: 341-346.

21) Vlahovic Z, Radojkovic D. 2010. Healthcare in Serbia in transition period. EPMA J 1: 601-606.

22) Kavarić S, Vuksanović M, Bozović D, Jovanović M, Jeremić V, Radojicić Z, Pekić S, Popović V. 2013. Body weight and waist circumference as predictors of vitamin D deficiency in patients with type 2 diabetes and cardiovascular disease. Vojnosanit Pregl 70: 163-169.

23) Milovanovic OZ, Milovanovic JR, Djukic A, Matovic M, Lucic AT, Glumbic N, Radovanovic AM, Jankovic SM. 2015. Variation in vitamin D plasma levels according to study load of biomedical students. Acta Pol Pharm 72: 213-215.

24) Doknic M, Maric NP, Britvic D, Pekic S, Damjanovic A, Miljic D, Stojanovic M, Radojicic Z, Jasovic Gasic M, Popovic V. 2011. Bone remodeling, bone mass and weight gain in patients with stabilized schizophrenia in real-life conditions treated with long-acting injectable risperidone. Neuroendocrinology 94: 246-254.

25) Jamilian H, Bagherzadeh K, Nazeri Z, Hassanijirdehi M. 2013. Vitamin D, parathyroid hormone, serum calcium and phosphorus in patients with schizophrenia and major depression. Int J Psychiatry Clin Pract 17: 30-34.

26) Stanojević Pirković M. 2012. Risk factors for disturbances of bone tissue homeostasis in patients with psychotic disorders. PhD Thesis. Faculty of Medical Sciences University of Kragujevac, Kragujevac (in Serbian).

27) Milovanovic O. 2014. Population pharmacokinetics of 25-hydroxyvitamin D in students. PhD Thesis. Faculty of Medical Sciences University of Kragujevac, Kragujevac (in Serbian).

28) Boricic K, Vasic M, Grozdanov J, Gudelj Rakic J, Zivkovic Sulovic M, Jacovic Knezevic N, Jovanovic V, Kilibarda B, Knezevic T, Krstic M, Miljus D, Mickovski Katalina N, Simić D. 2014. Results of research of Serbian population health, year 2013. Public Health Institute "Dr Milan Jovanovic Batut," Belgrade (in Serbian).

29) Francis R, Aspray T, Fraser W, Gittoes N, Javaid K, Macdonald H, Patel S, Selby P, Tanna N, Bowring C. 2013. Vitamin D and bone health: a practical clinical guideline for patient management. National Osteoporosis Society, Camerton Bath.

30) Holick MF, Binkley NC, Bischoff-Ferrari HA, Gordon CM, Hanley DA, Heaney RP, Murad MH, Weaver CM; Endocrine Society. 2011. Evaluation, treatment, and prevention of vitamin D deficiency: an Endocrine Society clinical practice guideline. J Clin Endocrinol Metab 96: 1911-1930.

31) Streiner DL, Norman GR. 2008. Health Measurement Scale-A Practical Guide to Their Development and Use, 4th ed. Oxford University Press, Oxford.

32) IOM (Institute of Medicine). 2010. Dietary Reference Intakes for Calcium and Vitamin D. The National Academies Press, Washington, DC.

33) Pludowski P, Karczmarewicz E, Bayer M, Carter G, Chlebna-Sokół D, Czech-Kowalska J, Dębski R, Decsi T, Dobrzańska A, Franek E, Głuszko P, Grant WB, Holick MF, Yankovskaya L, Konstantynowicz J, Książyk JB, Księżopolska-Orłowska K, Lewiński A, Litwin M, Lohner S, Lorenc RS, Lukaszkiewicz J, Marcinowska-Suchowierska E, Milewicz A, Misiorowski W, Nowicki M, Povoroznyuk V, Rozentryt P, Rudenka E, Shoenfeld Y, Socha P, Solnica B, Szalecki M, Tałałaj M, Varbiro S, Zmijewski MA. 2013. Practical guidelines for the supplementation of vitamin D and the treatment of deficits in Central Europe-recommended vitamin D intakes in the general population and groups at risk of vitamin D deficiency. Endokrynol Pol 64: 319-327.

34) Holick MF. 2007. Vitamin D deficiency. N Engl J Med 357: 266-281.

35) National Osteoporosis Foundation. 2010. Clinician's Guide to Prevention and Treatment of Osteoporosis. National Osteoporosis Foundation, Washington, DC.

36) Friedman PA. 2006. Agents affecting mineral ion homeostasis and bone turnover. In: Goodman \& Gilman's The Pharmacological Basis of Therapeutics (Brunton LL, Lazo JS, Parker KL, eds), 11th ed, p 16471678. McGraw-Hill, New York.

37) Teucher B, Dainty JR, Spinks CA, Majsak-Newman G, Berry DJ, Hoogewerff JA, Foxall RJ, Jakobsen J, Cashman KD, Flynn A, Fairweather-Tait SJ. 2008. Sodium and bone health: impact of moderately high and low salt intakes on calcium metabolism in postmenopausal women. J Bone Miner Res 23: 1477-1485.

38) Pohl HR, Wheeler JS, Murray HE. 2013. Sodium and potassium in health and disease. Met Ions Life Sci 13: 29-47.

39) Wu J, Carter A. 2007. Magnesium: the forgotten electrolyte. Aust Prescr 30: 102-105.

40) Madhusoodanan S, Bogunovic OJ, Moise D, Brenner R, Markowitz S, Sotelo J. 2002. Hyponatraemia associated with psychotropic medications. A review of the literature and spontaneous reports. Adverse Drug React Toxicol Rev 21: 17-29.

41) Prior JC, Langsetmo L, Lentle BC, Berger C, Goltzman D, Kovacs CS, Kaiser SM, Adachi JD, Papaioannou A, Anastassiades T, Towheed T, Josse RG, Brown JP, Leslie WD, Kreiger N; CaMOS Research Group. 2015. Ten-year incident osteoporosis-related fractures in the populationbased Canadian Multicentre Osteoporosis Study-comparing site and age-specific risks in women and men. Bone 71: 237-243.

42) Tuyen le D, Hien VT, Binh PT, Yamamoto S. 2016. Calcium and vitamin D deficiency in Vietnamese: recommendations for an intervention strategy. J Nutr Sci Vitaminol 62: 1-5.

43) Engelsen O. 2010. The relationship between ultraviolet radiation exposure and vitamin D status. Nutrients 2: 482-495.

44) Park S, Ham JO, Lee BK. 2014. A positive association of vitamin D deficiency and sarcopenia in 50 year old 
women, but not men. Clin Nutr 33: 900-905.

45) Robinson M, Whitehouse AJ, Newnham JP, Gorman S, Jacoby P, Holt BJ, Serralha M, Tearne JE, Holt PG, Hart PH, Kusel MM. 2014. Low maternal serum vitamin D during pregnancy and the risk for postpartum depression symptoms. Arch Womens Ment Health 17: 213-219.

46) Koster JB, Kühbauch BA. 2011. Vitamin D deficiency and psychiatric patients. Tijdschr Psychiatr 53: 561-565.

47) Schmid A, Walther B. 2013. Natural vitamin D content in animal products. Adv Nutr 4: 453-462.

48) Christakos S, Dhawan P, Verstuyf A, Verlinden L, Carmeliet G. 2016. Vitamin D: metabolism, molecular mechanism of action, and pleiotropic effects. Physiol Rev 96: 365-408.

49) Cieslak K, Feingold J, Antonius D, Walsh-Messinger J, Dracxler R, Rosedale M, Aujero N, Keefe D, Goetz D, Goetz R, Malaspina D. 2014. Low vitamin D levels predict clinical features of schizophrenia. Schizophr Res 159: $543-545$.

50) Chiang M, Natarajan R, Fan X. 2016. Vitamin D in schizophrenia: a clinical review. Evid Based Ment Health 19: 6-9.

51) Persson LJ, Aanerud M, Hiemstra PS, Hardie JA, Bakke PS, Eagan TM. 2012. Chronic obstructive pulmonary disease is associated with low levels of vitamin D. PLoS One 7: e38934.

52) Holy X, Collombet JM, Labarthe F, Granger-Veyron N, Bégot L. 2012. Effects of seasonal vitamin D deficiency and respiratory acidosis on bone metabolism markers in submarine crewmembers during prolonged patrols. J Appl Physiol (1985) 112: 587-596.

53) Merlo C, Ross C, Trummler M, Zeller A. 2012. Prevalence and symptoms of vitamin D deficiency in general practices. Praxis (Bern 1994) 101: 1417-1422.
54) Nerhus M, Berg AO, Dahl SR, Holvik K, Gardsjord ES, Weibell MA, Bjella TD, Andreassen OA, Melle I. 2015. Vitamin D status in psychotic disorder patients and healthy controls - the influence of ethnic background. Psychiatry Res 230: 616-621.

55) Menkes DB, Lancaster K, Grant M, Marsh RW, Dean P, du Toit SA. 2012. Vitamin D status of psychiatric inpatients in New Zealand's Waikato region. BMC Psychiatry 12: 68 .

56) Crews M, Lally J, Gardner-Sood P, Howes O, Bonaccorso S, Smith S, Murray RM, Di Forti M, Gaughran F. 2013. Vitamin D deficiency in first episode psychosis: a casecontrol study. Schizophr Res 150: 533-537.

57) The Ministry of Health of the Republic of Serbia. 2005. Strategy development of mental health care. Official Gazette Republic of Serbia No. 55/05 and 71/05 corrective. Official Gazette, Belgrade.

58) Glendenning P. 2015. Measuring vitamin D. Aust Prescr 38: $12-15$.

59) Jones E. 2014. Antipsychotics and osteoporosis: current awareness and practice in primary care. $\mathrm{Br} \mathrm{J}$ Gen Pract 64: 562-563.

60) Kido S, Kaneko I, Tatsumi S, Segawa H, Miyamoto K. 2013. Vitamin D and type II sodium-dependent phosphate cotransporters. Contrib Nephrol 180: 86-97.

61) Bodyak N, Ayus JC, Achinger S, Shivalingappa V, Ke Q, Chen YS, Rigor DL, Stillman I, Tamez H, Kroeger PE, Wu-Wong RR, Karumanchi SA, Thadhani R, Kang PM. 2007. Activated vitamin D attenuates left ventricular abnormalities induced by dietary sodium in Dahl salt-sensitive animals. Proc Natl Acad Sci USA 104: 16810-16815.

62) Strom BL, Kimmel SE. 2006. Textbook of Pharmacoepidemiology. John Wiley \& Sons, Chichester. 